\title{
ANALYSIS OF LEADING SECTORS POTENTIAL FOR ECONOMIC DEVELOPMENT PLANNING IN MALANG CITY
}

\author{
Ahmad Rizani*1 \\ ${ }^{1}$ Department of Development Economics, Faculty of Economics, Universitas Borneo Tarakan, Indonesia
}

\begin{abstract}
This study aims to identify and determine the leading sectors in Malang City to illustrate leading economic activities that can be developed to boost economic potential in Malang City. The analysis tools used include ShiftShare, Location Quotient (LQ), and Growth Ratio Model (GRM) analysis. The results show that: (1) shift-share analysis showed that the economy of Malang City during the period 2010-2016 increased by Rp. 12,926,565.5 million. The increase in economic performance in Malang City can be seen from 16 (sixteen) sectors of economic activity that are positive; (2) Location Quotient (LQ) analysis showed the leading sectors in Malang City consisting of 7 (seven) sectors, i.e. water procurement, garbage, waste and recycling management, construction, retail and wholesale trade, car and motorcycle repair, financial and insurance services, education services, health services, and social activities and other services sector; (3) Growth Ratio Model (GRM) estimation showed that the dominant sectors of growth and large contributions consist of the retail and wholesale trade car and motorcycle repair, transportation and warehousing, accommodation and food provision, information and communication, financial and insurance services, real estate, education services and health services and social activities sectors; (4) weighting results based on Shift-Share, Location Quotient (LQ) analysis, and Growth Ratio Model (GRM) showed that five sectors based on the highest potential weighting results are the health services and social activities, education services, construction, retail and wholesale trade car and motorcycle repair, and financial and insurance services sector.
\end{abstract}

Keywords: Economic Potential, Shift-Share, Location Quotient (LQ), Growth Ratio Model (GRM)

JEL Classification: R58;R11;041

\section{ARTICLE INFO}

Received: April $11^{\text {th }}, 2020$

Revised: May $1^{\text {st }}, 2020$

Accepted: May $6^{\text {th }}, 2020$

Online: June $15^{\text {th }}, 2020$

*Correspondence: Ahmad Rizani

E-mail:

ahmadrizani@gmail.com

To cite this document: Rizani,A., (2020). Analysis of Leading Sectors Potential for Economic Development Planning in Malang City. JDE (Journal of Developing Economies), Vol. 5 (1), 20-39.

\section{Introduction}

Traditionally, development means a continuous increase in a Gross Domestic Product (GDP) of a country. For a region, the meaning of traditional development is focused on the GRDP of a province, district, and city. Regional economic development is a process whereby local governments and all components of the society manage various existing resources and form a partnership pattern to create new jobs and stimulate the development of economic activities in the region. Measurements for the success of development can be seen from economic growth, economic structure, and the smaller income inequality between residents, between regions and between sectors (Arsyad, 2004: 7). 
In regional economic development, the development is generally focused on economic development through economic growth efforts. Economic growth is related to an increase in the production of goods and services which, among others, is measured by a measurement called Gross Regional Domestic Product (GRDP). The main factor that determines regional economic growth is the demand for goods and services from outside the region so that local resources will be able to generate regional wealth because it can create employment opportunities in the region (Boediono, 1999: 1).

One of the important factors that determine the success of regional development is the planning process because economic development cannot be handled solely by the market mechanism. Planning can be defined as a continuous process that includes decisions on choices of various alternative uses of resources to achieve certain goals in the future (Arsyad, 2004: 19).

Widodo (2006: 111) stated that development planning activities to develop the economic sector began by identifying the leading sectors or potential of the regional economy. Economic development planning requires a variety of statistical data as a basis for establishing policy strategies so that development goals can be achieved appropriately. Two main factors need to be considered in identifying potential regional economic activities. First, it is important to identify a leading economic sector or one that has competitiveness in the past few years and the prospect of a future economic sector. Second is identifying the economic sector has the potential to be developed in the future even though at present it does not have a good level of competitiveness. By identifying the potential of regional economic activities, development policies can be developed based on the efforts to increase economic growth.

Some of the descriptions above show that research on identifying sectors that are leading/superior, especially in Malang City, is very important to be studied in more detail because by knowing the economic potential that exists in the city of Malang, the development performance that has been done can be assessed and regional development planning in the future can be more directed and can be used as a basis in implementing priority scale policies to optimize the utilization of regional economic potential to accelerate economic growth.

\section{Literature Review Economic Growth Theory}

In economic development policies in general, the policies are intended to improve the welfare of the community in the broadest sense. Economic development is said to increase if there is economic growth. A region is said to experience economic growth if there is an increase in the real Gross Regional Domestic Product (GRDP) in the region. If the rate of economic growth is negative, it means that economic activities show a decline, and vice versa if the rate of economic growth is positive, it means that economic activities show an increase (Arsyad, 2004: 145).

Todaro (2000: 146) says that the process of economic growth has a close relationship with high structural and sectoral changes. In some changes, the main structural components include a gradual shift in agricultural activities towards the non-agricultural sector and from the industrial sector to the service sector.

According to Penox (1970) in Arsyad (2004: 147-148), the central theory of growth is a theory that becomes the basis and strategy of regional policy that is widely applied in various countries. Essentially they explain the cores of growth. First, in the development process, a leading industry will emerge ( $L^{\prime}$ Industrie Matrice) which is the main driving industry in the development of a region. The linkages between industries are very close; therefore the development of leading industries will influence the development of other industries that are 
closely related to these leading industries. Second, the concentration of industry in a region will accelerate economic growth, because industrial concentration will create a different consumption pattern among regions, hence the development of the industry in the region will affect the development of other regions. Third, the economy is a combination of relatively active industrial systems (leading industries) with passive industries, they are industries that only depend on leading industries or growth centers in relatively developed regions will affect less developed regions.

According to some classical economists, Adam Smith, David Ricardo, Thomas Robert Malthus, and John Stuart Mill, as well as neo-classical economists, Robert Solow and Trevor Swan, they suggest that four factors influence economic growth (1) population, (2) the amount of capital goods stock, (3) land area and natural wealth, and (4) the level of technology used.

\section{Economic Base Theory}

In improving the regional economy, the economic base theory is one of the theories developed. This economic base theory states that the main determinant of economic growth in a region is directly related to the demand for goods and services from outside the region. The production process in the sector or industry in the region that uses local production resources, including labor and raw materials where the output is exported will produce economic growth, increase per capita income, and create employment opportunities in the region (Tambunan, 2003: 182).

The economic basis approach is based on the opinion that what needs to be developed in a region is the ability to produce and sell these products efficiently and effectively. North (1964) in Arsyad (2004: 154) stated that the export sector (base sector) plays an important role in regional development. It is because the base sector can provide an important contribution to regional development, in which exports directly increase the income of production factors and regional income.

Bendavid-Val (1991: 77) suggested that the economic base theory is regional growth which is highly dependent on demand from outside the region for regional products. It can be explained that the growth or decline of the regional economy is determined by its ability to export outside the region. In exporting the activities may include both in the form of goods and services including labor. Activities that carry out such exports in the industrial form are also called base sectors.

\section{Regional Economic Potential}

Regional economic potential is the economic capacity that exists in the region that may and is feasible to be developed so that it will continue to develop into the livelihoods of the local society, and even help the regional economy as a whole to develop itself and become sustainable (Suparmoko, 2002: 28).

The potential economic sector has an important position in regional economic development. A sector can be categorized as a potential/leading sector if the sector in a particular region can compete with the same sector produced by other regions in the national or domestic market (Wijaya, 1996: 2).

Yusuf (1999: 221) stated that in identifying leading/potential regional economic activities, it is recommended to use more than one analytical tool that could combine aspects of contribution and growth in the regional economic sector. 


\section{Data and Research Methods Data}

The data used in this study are secondary data for 8 years starting from 2010 to 2016. Data sources were obtained from several sources of official government institutions, including the East Java Province Central Bureau of Statistics (BPS) and Malang City Central Bureau of Statistics (BPS).

The data collection method used in this study was carried out utilizing the library research approach it is a series of activities relating to the method of collecting library data, reading, recording, and processing research materials (Zed, 2004: 3). Therefore, the researcher collects data and then examines books or other reading sources that are relevant to this research.

\section{Analysis Tools \\ Shift-Share Analysis}

Mo, S.W., et al. (2020) state that shift-share analysis is a simple instrument to compare interregional performance. According to Creamer (1943) in Soepono (1993: 44) about Shift Share analysis technique, it divides growth as a change (D) of variables in a region such as, income or output over a certain period that influences provincial growth $(\mathrm{N})$, industrial mix $(\mathrm{M})$, and competitive advantage $(\mathrm{C})$. To analyze the sector $\mathrm{i}$ in region $\mathrm{j}$ it is formulated mathematically as follows:

$$
D_{i j}=N_{i j}+M_{i j}+C_{i j}
$$

where:

$D_{i j} \quad=$ change of GRDP sector variable $\mathrm{i}$ in regionj

$N_{i j} \quad=E_{i j} . r_{n}$ (provincial sector growth i in regionj)

$M_{i j}=E_{i j} .\left(r_{i n}-r_{n}\right)$ (sector industrial mixi in regionj)

$C_{i j} \quad=E_{i j} .\left(r_{i j}-r_{i n}\right)$ (sector competitive advantage $\mathrm{i}$ in $\mathrm{j}$ region)

Equation represents the growth rate in the sector i region $\mathrm{j}$, represents the growth rate in sector $i$ in the reference region, is the economic growth of the reference region, which then can be stated as follows:

$$
\begin{aligned}
r_{i j} & =\left(E_{i j}^{*}-E_{i j}\right) / E_{i j} \\
r_{i n} & =\left(E_{i n}^{*}-E_{i n}\right) / E_{i n} \\
r_{n} & =\left(E_{n}^{*}-E_{n}\right) / E_{n}
\end{aligned}
$$

where:

$$
\begin{array}{ll}
E_{i j} & =\text { value added to sector } \mathrm{i} \text { in studied region } \mathrm{j} \\
E_{i n} & =\text { value added to sector } \mathrm{i} \text { in the reference region } \\
E_{n} & =\text { economic growth in the reference region }
\end{array}
$$

All variables measured on a base year and superscript $(*)$ indicate economic growth in the final year analyzed. For a region, national or provincial growth, industrial mix, and competitive advantage can be determined for a sector or added up for all sectors as a whole. The Shift Share equation for a particular sector (sector i) in a particular region (region j) is: 


$$
D_{i j}=E_{i j}\left(r_{n}\right)+E_{i j}\left(r_{i n}-r_{n}\right)+E_{i j}\left(r_{i j}-r_{i n}\right)
$$

\section{Location Quotient (LQ) Analysis}

According to Tarigan (2007: 82) analysis of Location Quotient (LQ) is a simple indicator that shows the "strength" of the large and small sectors in a region compared to the same sector in a wider region. Khusaini (2015) also states that LQ used to determine the level of specialization sector or leading sector. The higher the LQ value of a sector means the higher the competitive advantage of the region concerned in developing the sector. The calculation of $L Q$ aims to describe the comparative advantage of a region with other regions. The formula used in determining the base sector or leading sector is:

$$
L Q=\frac{E_{i j} / E_{j}}{E_{\text {in }} / E_{n}}
$$

where:

$L Q \quad=$ Location Quotientof Malang City

$E_{i j} \quad=$ GRDP sector of Malang City

$E_{j} \quad=$ GRDP total of Malang City

$E_{i n} \quad=$ GRDP sector of East Java Province

Moreover, Bendavid-Val (1991) in Kuncoro (2004: 183) provided a measurement of the specialization rate with the following criteria:

- $L Q>1$ means that the level of specialization of a certain sector at the City level is greater than the same sector at the Provincial level.

- $L Q=1$ means that the level of specialization of a certain sector at the City level is the same with the same sector at the Provincial level.

- LQ> 1 means that the level of specialization of a certain sector at the City level is smaller than the same sector at the Provincial level.

\section{Growth Ratio Model}

Yusuf (1999: 221-223) advocated the use of more than one analytical tool in identifying the leading economic activities of a region. For this reason, the Growth Ratio Model (GRM) was used in this study to analyze the leading economic sectors. This model is a further modification of Shift-Share analysis.

To formulate the analysis of the Growth Ratio Model are as follows:

1) The growth ratio of the reference region is the ratio between the growth rate of sector $i$ and the total growth rate of activity (GRDP) in the reference region, with the formula being:

$$
R \operatorname{Pr}=\frac{\Delta E_{i r} / E_{i r(t)}}{\Delta E_{r} / E_{r(t)}}
$$

where:

$R P r \quad=$ Growth Ratio of East Java Province

$\Delta E_{i r} \quad=$ Changes in East Java Province GRDP in sector $\mathrm{i}$ in the year of analysis

$E_{i r(t)} \quad=$ East Java Province GRDP in sector $\mathrm{i}$ in the initial year of the study period 


\section{$\Delta E_{r} \quad=$ Changes in East Java Province GRDP in sector $\mathrm{i}$ in the year of analysis \\ $E_{r(t)} \quad=$ East Java Province GRDP in the initial year of the study period}

2) The growth ratio of the study region is the ratio between the growth rate of the sector $i$ in Malang City with the growth rate of the same sector in the reference region, with the formula being:

$$
R P S=\frac{\Delta E_{i j} / E_{i j(t)}}{\Delta E_{i r} / E_{i r(t)}}
$$

where:

RPS = Growth Ratio of Malang City

$\Delta E_{i j} \quad=$ Changes in Malang City GRDP in sector $i$ in the year of analysis

$E_{i j(t)} \quad=$ Malang City GRDP in sector $\mathrm{i}$ in the initial year of the study period

$\Delta E_{r} \quad=$ Changes in East Java Province GRDP in sector $\mathrm{i}$ in the year of analysis

$E_{r(t)} \quad=$ East Java Province GRDP in the initial year of the study period

According to Yusuf (1999: 223-225) the combination of the results of RPr and RPs can describe leading economic activities with four classifications:

- The value of RPr (+) and RPs (+)means the activity is good in both the reference region and in the study region and has prominent growth.

- The value of $\operatorname{RPr}(+)$ and $\operatorname{RPs}(-)$ means that the activity in the reference region has prominent growth but in the study region the growth has not been prominent.

- The value of $\operatorname{RPr}(-)$ and RPs (+)means that the activity in the reference region does not have prominent growth but in the study region the growth is prominent.

- Fourth classification is when RPr (-) and RPs (-), it means the activity in both the reference region and in the study regiondoes not have prominent growth.

\section{Determination of the Assessment Weight of the Leading Sector}

To see and identify the leading sectors in Malang City, various types of analysis tools have been used. Because of using more than one analytical tool, the results of each analysis (Shift-Share, LQ, and MRP) are given a weighting rating by ranking the values set for each sector. The determination of ratings for each economic sector in MalangCity is done by giving a number that corresponds to the number of economic sectors as many as 17 (seventeen) sectors. Subsequently, the value of 1 (one) up to 17 (seventeen) is given following the value of each sector and if there are sectors that have the same value then the same rank is given.

\section{Finding and Discussion}

Based on the objectives of the study, the data obtained in this study were analyzed by the following analysis tools:

\section{Shift-Share Analysis}

In providing an overview of the developing sectors in increasing the economic potential of Malang City compared to the economic development of East Java Province, Shift-Share analysis tools are used. The results of the Shift Share analysis can be seen in the table below: 
Table 1: Calculation Results of Shift Share in Malang City 2010-2016

\begin{tabular}{|c|c|c|c|c|}
\hline Sector & $N_{i j}=E_{i j} . r_{n}$ & $\begin{array}{c}M_{i j}= \\
E_{i j} \cdot\left(r_{i n}-r_{n}\right)\end{array}$ & $\begin{array}{c}C_{i j}= \\
E_{i j} \cdot\left(r_{i j}-r_{i n}\right)\end{array}$ & $\begin{array}{c}D_{i j}= \\
N_{i j}+M_{i j}+C_{i j}\end{array}$ \\
\hline $\begin{array}{l}\text { Agriculture, forestry and fish- } \\
\text { eries }\end{array}$ & $42,679.80$ & $-18,859.50$ & $-18,287.70$ & $5,532.60$ \\
\hline Mining and excavation & $18,559.90$ & $-1,316.20$ & $-25,367.00$ & $-8,123.30$ \\
\hline Processing industry & $3,788,212.80$ & $-129,223.40$ & $-2,247,515.30$ & $1,411,474.10$ \\
\hline $\begin{array}{l}\text { Electricity and gas procure- } \\
\text { ment }\end{array}$ & $5,329.80$ & $-5,352.60$ & $4,123.60$ & $4,100.80$ \\
\hline $\begin{array}{l}\text { Water procurement, garbage, } \\
\text { waste and recycling manage- } \\
\text { ment }\end{array}$ & $28,592.00$ & $-10,120.30$ & $4,505.50$ & $22,977.20$ \\
\hline Construction & $1,519,357.70$ & $-17,268.80$ & $479,484.30$ & $1,981,573.10$ \\
\hline $\begin{array}{l}\text { Retail and wholesale trade car } \\
\text { and motorcycle repair }\end{array}$ & $3,914,519.40$ & $494,343.00$ & $82,281.10$ & $4,491,143.40$ \\
\hline $\begin{array}{l}\text { Transportation and warehous- } \\
\text { ing }\end{array}$ & $314,276.50$ & $74,622.90$ & $-17,566.20$ & $371,333.20$ \\
\hline $\begin{array}{l}\text { Accommodation and food } \\
\text { provision }\end{array}$ & $511,171.10$ & $170,957.60$ & $93,517.70$ & $775,646.40$ \\
\hline $\begin{array}{l}\text { Information and communica- } \\
\text { tion }\end{array}$ & $532,336.50$ & $314,865.30$ & $54,977.50$ & $902,179.30$ \\
\hline $\begin{array}{l}\text { Financial and insurance ser- } \\
\text { vices }\end{array}$ & $307,702.00$ & $194,937.70$ & $-32,819.90$ & $469,819.80$ \\
\hline Real estate & $183,199.10$ & $31,356.70$ & $22,021.50$ & $236,577.30$ \\
\hline Corporate services & $92,019.40$ & $-4,037.20$ & $25,145.00$ & $113,127.20$ \\
\hline $\begin{array}{l}\text { Government administration, } \\
\text { defense and social security }\end{array}$ & $235,365.20$ & $-126,546.90$ & $-34,724.90$ & $74,093.40$ \\
\hline Education services & $910,771.60$ & $179,238.80$ & $190,558.50$ & $1,280,568.90$ \\
\hline $\begin{array}{l}\text { Health services and social } \\
\text { activities }\end{array}$ & $270,021.70$ & $187,611.80$ & $49,280.90$ & $506,914.40$ \\
\hline Other services & $457,323.30$ & $-131,242.90$ & $-38,452.70$ & $287,627.70$ \\
\hline Total & $13,131,437.90$ & $1,203,965.80$ & $1,408,838.20$ & $12,926,565.50$ \\
\hline
\end{tabular}

From the table above, it can be seen that the economy of Malang City in the 20102016 period increased by Rp. 12,926,565.5 million. The increase in economic performance in MalangCity can be seen from 16 (sixteen) sectors of economic activity that are positive. The increase in economic growth in MalangCity is caused by the effect of the economic growth of East Java Province, industrial mix and competitive advantage, for more details can be detailed as follows:

\section{Effect of Economic Growth in East Java Province $\left(N_{i j}\right)$}

The effect of economic growth in EastJava Province $\left(N_{i j}\right)$ on economic growth in Malang City contributed positively to Rp.13,131,437.9 million. When viewed from the sectorial economic growth of MalangCity compared to the relative growth rate of the same economic sector at the provincial level, it shows that on average the economic sectors that are at the city level are relatively higher than the sectors at the provincial level. 


\section{Effect of Industrial Mix $\left(M_{i j}\right)$}

The effect of the industrial mix $\left(M_{i j}\right)$ made a positive contribution of Rp.1,203,965.8 million. Judging from the output produced by the industrial mix, most sectors of the economy have positive and negative impacts. Positive impacts occur in the retail and wholesale trade car and motorcycle repair sector, transportation and warehousing sector, accommodation and food provision sector, information and communication sector, financial and insurance services sector, real estate sector, education services sector, and health services and social activities sector. This positive value has a faster growth rate than the overall economic sector growth. Negative impacts occur in the agriculture, forestry and fisheries sector, mining and excavation sector, processing industry sector, electricity and gas procurement sector, water procurement, garbage, waste and recycling management sector, construction sector, corporate services sector, government administration, defense and social security sector and other services sectors. This negative value has a slower growth rate than the overall economic sector growth.

\section{Effect of Competitive Advantage ( $\left.C_{i j}\right)$}

Competitive advantage $\left(C_{i j}\right)$ in each economic sector has decreased with a negative total value of Rp. $-1,408,838.2$ million. The economic sector that shows a good level of competitiveness is the electricity and gas procurement sector, the water procurement sector, garbage, waste and recycling management sector, construction sector, retail and wholesale trade car and motorcycle repair sector, accommodation and food provision sector, information and communication sector, real estate sector, corporate services sector, education services sector and the health services and social activities sector. While the sectors experiencing a competitive decline were the agriculture, forestry and fisheries sector, mining and excavation sector, processing industry sector, transportation and warehousing sector, financial and insurance services sector, government administration, defense and social security sector and other services sectors.

\section{Location Quotient (LQ) Analysis}

In determining whether the sector is superior/leading (potential) or not Location Quotient (LQ) analysis method was used. The results of Location Quotient (LQ) analysis can be seen in the table below:

Table 2: Calculation Results of Location Quotient (LQ) in Malang City, 2010-2016

\begin{tabular}{|c|c|c|c|c|c|c|c|c|c|}
\hline \multirow{2}{*}{ Sector } & \multicolumn{7}{|c|}{ LQ Malang City } & \multirow{2}{*}{ Average } & \multirow{2}{*}{ Explanation } \\
\hline & 2010 & 2011 & 2012 & 2013 & 2014 & 2015 & 2016 & & \\
\hline $\begin{array}{l}\text { Agriculture, forestry } \\
\text { and fisheries }\end{array}$ & 0.02 & 0.02 & 0.02 & 0.02 & 0.02 & 0.02 & 0.02 & 0.02 & Non-Base Sector \\
\hline $\begin{array}{l}\text { Mining and excava- } \\
\text { tion }\end{array}$ & 0.03 & 0.02 & 0.02 & 0.02 & 0.02 & 0.02 & 0.02 & 0.02 & Non-Base Sector \\
\hline Processing industry & 0.98 & 0.96 & 0.93 & 0.89 & 0.85 & 0.83 & 0.81 & 0.89 & Non-Base Sector \\
\hline $\begin{array}{l}\text { Electricity and gas } \\
\text { procurement }\end{array}$ & 0.09 & 0.1 & 0.11 & 0.11 & 0.11 & 0.11 & 0.12 & 0.11 & Non-Base Sector \\
\hline $\begin{array}{l}\text { Water procurement, } \\
\text { garbage, waste and } \\
\text { recycling manage- } \\
\text { ment }\end{array}$ & 2 & 1.94 & 2.02 & 2.1 & 2.16 & 2.13 & 2.12 & 2.07 & Base Sector \\
\hline Construction & 1.28 & 1.3 & 1.31 & 1.32 & 1.36 & 1.38 & 1.4 & 1.34 & Base Sector \\
\hline
\end{tabular}




\begin{tabular}{|c|c|c|c|c|c|c|c|c|c|}
\hline \multirow{2}{*}{ Sector } & \multicolumn{7}{|c|}{ LQ Malang City } & \multirow{2}{*}{ Average } & \multirow{2}{*}{ Explanation } \\
\hline & 2010 & 2011 & 2012 & 2013 & 2014 & 2015 & 2016 & & \\
\hline $\begin{array}{l}\text { Retail and wholesale } \\
\text { trade car and motor- } \\
\text { cycle repair }\end{array}$ & 1.69 & 1.67 & 1.67 & 1.68 & 1.69 & 1.7 & 1.71 & 1.69 & Base Sector \\
\hline $\begin{array}{l}\text { Transportation and } \\
\text { warehousing }\end{array}$ & 0.88 & 0.85 & 0.86 & 0.85 & 0.85 & 0.85 & 0.87 & 0.86 & Non-Base Sector \\
\hline $\begin{array}{l}\text { Accommodation and } \\
\text { food provision }\end{array}$ & 0.82 & 0.81 & 0.84 & 0.85 & 0.87 & 0.87 & 0.86 & 0.84 & Non-Base Sector \\
\hline $\begin{array}{l}\text { Information and } \\
\text { communication }\end{array}$ & 0.84 & 0.84 & 0.83 & 0.83 & 0.85 & 0.86 & 0.87 & 0.85 & Non-Base Sector \\
\hline $\begin{array}{l}\text { Financial and insur- } \\
\text { ance services }\end{array}$ & 1.05 & 1.04 & 1.03 & 1.02 & 1.02 & 1.02 & 1.03 & 1.03 & Base Sector \\
\hline Real estate & 0.85 & 0.84 & 0.84 & 0.84 & 0.85 & 0.86 & 0.88 & 0.85 & Non-Base Sector \\
\hline Corporate services & 0.89 & 0.9 & 0.93 & 0.92 & 0.93 & 0.95 & 0.97 & 0.93 & Non-Base Sector \\
\hline $\begin{array}{l}\text { Government admin- } \\
\text { istration, defense } \\
\text { and social security }\end{array}$ & 0.67 & 0.67 & 0.67 & 0.67 & 0.67 & 0.66 & 0.64 & 0.66 & Non-Base Sector \\
\hline Education services & 2.75 & 2.8 & 2.77 & 2.77 & 2.83 & 2.88 & 2.93 & 2.82 & Base Sector \\
\hline $\begin{array}{l}\text { Health services and } \\
\text { social activities }\end{array}$ & 3.77 & 3.66 & 3.68 & 3.71 & 3.75 & 3.86 & 3.95 & 3.77 & Base Sector \\
\hline Other services & 2.21 & 2.22 & 2.24 & 2.21 & 2.19 & 2.17 & 2.16 & 2.2 & Base Sector \\
\hline
\end{tabular}

\section{Growth Ratio Model (GRM) Analysis}

The Growth Ratio Model (GRM) is a modification of the Shift-Share model in which the GRM model produces growth in the form of a coefficient number. The results of the analysis of the growth ratio model can be seen in the table below:

Table 3: Calculation results of Growth Ratio Model East Java Province and Malang City, 2010-2016

\begin{tabular}{|c|c|c|c|c|}
\hline \multirow{3}{*}{ Sector } & \multicolumn{4}{|c|}{ Growth Ratio Model (GRM) } \\
\hline & \multicolumn{2}{|c|}{$\mathrm{RPr}$} & \multicolumn{2}{|c|}{ RPs } \\
\hline & $\mathbf{R}$ & $\mathbf{N}$ & $\mathbf{R}$ & $\mathbf{N}$ \\
\hline Agriculture, forestry and fisheries & 0.56 & - & 0.13 & - \\
\hline Mining and excavation & 0.93 & - & -0.44 & - \\
\hline Processing industry & 0.97 & - & 0.38 & - \\
\hline Electricity and gas procurement & 0 & - & 0.78 & - \\
\hline $\begin{array}{l}\text { Water procurement, garbage, waste and recycling manage- } \\
\text { ment }\end{array}$ & 0.65 & - & 0.82 & - \\
\hline Construction & 0.99 & - & 1.32 & + \\
\hline Retail and wholesale trade car and motorcycle repair & 1.13 & + & 1.17 & + \\
\hline
\end{tabular}




\begin{tabular}{llccc}
\hline \multirow{2}{*}{\multicolumn{1}{c}{ Sector }} & \multicolumn{3}{c}{ Growth Ratio Model (GRM) } \\
\cline { 2 - 5 } & \multicolumn{2}{c}{$\mathbf{R P r}$} & \multicolumn{2}{c}{ RPs } \\
\cline { 2 - 5 } & $\mathbf{R}$ & $\mathbf{N}$ & $\mathbf{R}$ & $\mathbf{N}$ \\
\hline Transportation and warehousing & 1.24 & + & 1.2 & + \\
\hline Accommodation and food provision & 1.33 & + & 1.54 & + \\
\hline Information and communication & 1.59 & + & 1.72 & + \\
\hline Financial and insurance services & 1.63 & + & 1.55 & + \\
\hline Real estate & 1.17 & + & 1.31 & + \\
\hline Corporate services & 0.96 & - & 1.25 & + \\
\hline Government administration, defense and social security & 0.46 & - & 0.32 & - \\
\hline Education services & & & & \\
\hline Health services and social activities & 1.2 & + & 1.43 & + \\
\hline Other services & 1.69 & + & 1.91 & + \\
\hline
\end{tabular}

To combine the results from RPr and RPs then leading sectors can be classified to illustrate the leading economic activities in Malang City according to four classifications below:

Classification 1, in which the value of $\operatorname{RPr}(+)$ and $\operatorname{RPs}(+)$ means the activity is good in both the reference region and in the study region and has prominent growth. By looking at table 3 , the leading sectors are the retail and wholesale trade car and motorcycle repair sector, transportation and warehousing sector, accommodation and food provision sector, information and communication sector, financial and insurance services sector, real estate sector, education services sector, and health services and social activities sector

Classification 2, in which the value of $\operatorname{RPr}(+)$ and $\operatorname{RPs}(-)$ means that the activity in the reference region has prominent growth but in the study region the growth has not been prominent. By looking at table 3 , there is no sector in this classification.

Classification 3, in which the value of RPr (-) and RPs (+) means that the activity in the reference region does not have prominent growth but in the study region the growth is prominent. By looking at table 3, the sectors are construction sector and corporate services sector.

Classification 4, in which the values of RPr (-) and RPs (-), it means the activity in both the reference region and in the study region does not have prominent growth. By looking at table 3 , the sectors are agriculture, forestry, and fisheries sector, mining and excavation sector, processing industry sector, electricity and gas procurement sector, water procurement, garbage, waste and recycling management sector, government administration, defense and social security sector, and other services sector.

\section{Weighting Leading Sectors Rating}

The analysis results that have been obtained using Shift-Share, Location Quotient (LQ), and Growth Ratio Model (GRM) analysis tools are then weighted to obtain an overview of potential economic sectors, as shown in Table 4.

From the table above the ranks of each sector's weighting results based on the ShiftShare, Location Quotient (LQ), and Growth Ratio Model (GRM) analysis where5 sectors according to the highest rank of the weighting results, the most potential are health services and social activities sectors, education services sector, construction sector, retail and wholesale trade car and motorcycle repair sector, and financial and insurance services sector. 
Table 4: Weighting Results Based on the Shift-Share, Location Quotient (LQ), and Growth Ratio Model (GRM) analysis in Malang City, 2010 - 2016

\begin{tabular}{|c|c|c|c|c|c|c|c|c|}
\hline Sector & Shift-Share () & Value & LQ & Value & $\begin{array}{l}\text { MRP } \\
\text { (RPs) }\end{array}$ & Value & $\begin{array}{l}\text { Total } \\
\text { Value }\end{array}$ & Rank \\
\hline Agriculture, forestry and fisheries & $5,532.60$ & 3 & 0.022 & 2 & 0.132 & 2 & 7 & 13 \\
\hline Mining and excavation & $-8,123.30$ & 1 & 0.021 & 1 & -0.445 & 1 & 3 & 14 \\
\hline Processing industry & $1,411,474.10$ & 15 & 0.893 & 9 & 0.379 & 4 & 28 & 8 \\
\hline Electricity and gas procurement & $4,100.80$ & 2 & 0.109 & 3 & 0.782 & 6 & 11 & 12 \\
\hline $\begin{array}{l}\text { Water procurement, garbage, } \\
\text { waste and recycling management }\end{array}$ & $22,977.20$ & 4 & 2.068 & 14 & 0.816 & 7 & 25 & 10 \\
\hline Construction & $1,981,573.10$ & 16 & 1.338 & 12 & 1.325 & 12 & 40 & 3 \\
\hline $\begin{array}{l}\text { Retail and wholesale trade car } \\
\text { and motorcycle repair }\end{array}$ & $4,491,143.40$ & 17 & 1.686 & 13 & 1.165 & 8 & 38 & 4 \\
\hline Transportation and warehousing & $371,333.20$ & 9 & 0.857 & 8 & 1.2 & 9 & 26 & 9 \\
\hline $\begin{array}{l}\text { Accommodation and food pro- } \\
\text { vision }\end{array}$ & $775,646.40$ & 12 & 0.844 & 5 & 1.541 & 14 & 31 & 7 \\
\hline Information and communication & $902,179.30$ & 13 & 0.846 & 6 & 1.722 & 16 & 35 & 6 \\
\hline Financial and insurance services & $469,819.80$ & 10 & 1.032 & 11 & 1.551 & 15 & 36 & 5 \\
\hline Real estate & $236,577.30$ & 7 & 0.852 & 7 & 1.312 & 11 & 25 & 10 \\
\hline Corporate services & $113,127.20$ & 6 & 0.928 & 10 & 1.249 & 10 & 26 & 9 \\
\hline $\begin{array}{l}\text { Government administration, } \\
\text { defense and social security }\end{array}$ & $74,093.40$ & 5 & 0.664 & 4 & 0.32 & 3 & 12 & 11 \\
\hline Education services & $1,280,568.90$ & 14 & 2.821 & 16 & 1.428 & 13 & 43 & 2 \\
\hline $\begin{array}{l}\text { Health services and social activ- } \\
\text { ities }\end{array}$ & $506,914.40$ & 11 & 3.768 & 17 & 1.907 & 17 & 45 & 1 \\
\hline Other services & $287,627.70$ & 8 & 2.198 & 15 & 0.639 & 5 & 28 & 8 \\
\hline
\end{tabular}

\section{Conclusion}

First, the Shift-Share analysis results show that the structure of the economy from the 2010-2016 observations in Malang City compared to East Java Province increased by Rp. $12,926,565.5$ million, this was due to several factors, i.e. the effect of East Java Province's economic growth of Rp13,131,437.9million, the effect of the industrial mix amounted to $\mathrm{Rp} 1,203,965.8$ million and the effect of competitive advantage was $\mathrm{Rp}-1,408,838.2$ million.

Second, Based on the LQ analysis of leading sectors in Malang City during 2010-2016 period of the 17 (seventeen) economic sectors in the Gross Regional Domestic Product (GRDP) of Malang City, there are 7 (seven) sectors that have an LQ> 1 or leading (potential)sectors, i.e. water procurement, garbage, waste and recycling management sector, construction sector, retail and wholesale trade, car and motorcycle repair sector, financial and insurance services sector, education services sector, health services sector and social activities sector and other services sector.

Third, The calculation of the Growth Ratio Model (GRM) analysis shows that based on the combination of RPr and RPs the dominant sectors of growth include the retail and wholesale trade car and motorcycle repair sector, transportation and warehousing sector, accommodation and food provision sector, information and communication sector, financial and insurance services sector, real estate sector, education services sector and health services and social activities sectors 
Weighting results based on Shift-Share, Location Quotient (LQ), and Growth Ratio Model (GRM) analysis obtained 5 sectors based on the highest potential weighting results, i.e. the health services and social activities sectors, education services sector, construction sector, retail and wholesale trade car and motorcycle repair sector, and financial and insurance services sector.

\section{Recommendations}

From the results of the research obtained, some suggestions can be considered by Malang City government:

1) For regional development in Malang to be more successful, Malang City Government needs to determine development priorities based on its economic potential through the development of leading or potential sectors.

2) To avoid gaps and inequality between sectors, Malang City Government must utilize the leading and potential sectors to increase public welfare. Efforts that can be made include:

a. Building and improving infrastructure in supporting development such as roads, bridges, transportation and communication.

b. Creating a conducive investment climate through regional policies that stimulate the emergence of new investments such as convenient licensing and mapping of spatial and regional areas that support investment.

3) Malang City has a variety of potential sectors that are expected to increase employment to impact positively on the economy. One of which is reducing poverty and unemployment. To overcome poverty and unemployment, in addition to using a sectorial approach, one of the steps that must be taken is to increase labor-intensive economic activities.

\section{References}

Arsyad, Lincolin. (2004). Ekonomi Pembangunan. Edisi Keempat. STIE YKPN. Yogyakarta

Bendavid-Val, Avron. (1991). Regional and Local Economic Analysis for Practitioner. Four Edition. Sage Publication inc. California, USA.

Boediono. (1999). Teori Pertumbuhan Ekonomi, Edisi Pertama. Penerbit BPFE. Yogyakarta

Khusaini, M. (2015). A Shift-Share Analysis on Regional Competitiveness - A Case of Banyuwangi District, East Java, Indonesia. Social and Behavioral Science, 738-744.

Kuncoro, M. (2004). Otonomi dan Pembangunan Daerah : Reformasi, Perencanaan, Strategi, dan Peluang, Penerbit Erlangga, Jakarta.

Mo, S. W., Lee, K. B., Lee, Y. J., \& Park, H. G. (2020). Analysis Of Import Changes Through ShiftShare, Location Quotient and BCG Techniques: Gwangyang Port in Asia. The Asian Journal of Shipping and Logistics.

Soepono, Prasetyo. (1993). Analisis Shift-Share Perkembangan dan Penerapan. Jurnal Ekonomi dan Bisnis, No. 1 Tahun III: 43-54.

Suparmoko, M. (2002). Ekonomi Publik, Untuk Keuangan dan Pembangunan Daerah. Penerbit Andi, Yogyakarta.

Tambunan, Tulus T.H. (2003). Perekonomian Indonesia, Ghalia Indonesia, Jakarta.

Tarigan, Robinson, (2007). Ekonomi Regional Teori dan Aplikasi, PT Bumi Aksara, Jakarta. 
Todaro, M.P. (2000). Pembangunan Ekonomi di Dunia Ketiga, Edisi Ketujuh. Penerbit Airlangga, Jakarta.

Widodo, Tri. (2006). Perencanaan Pembangunan : Aplikasi Komputer (Era Otonomi Daerah). Penerbit UPP STIM YKPN, Yogyakarta.

Wijaya, A. (1996). Jurnal Ekonomi Pembangunan Pilihan Pembangunan Industri : Kasus DKI Jakarta, No IV (2), Jakarta.

Yusuf, Maulana. (1999). Model Rasio Pertumbuhan (MRP) Sebagai Salah Satu Alat Analisis Alternatif Dalam Perencanaan Wilayah Dan Kota, Aplikasi Model : Bangka Belitung, Ekonomi dan Keuangan Indonesia, Vol. XLVII, No. 2 : 221-233.

Zed, Mustika. (2004). Metode Penelitian Kepustakaan. Penerbit Yayasan Obor Nasional, Jakarta. 


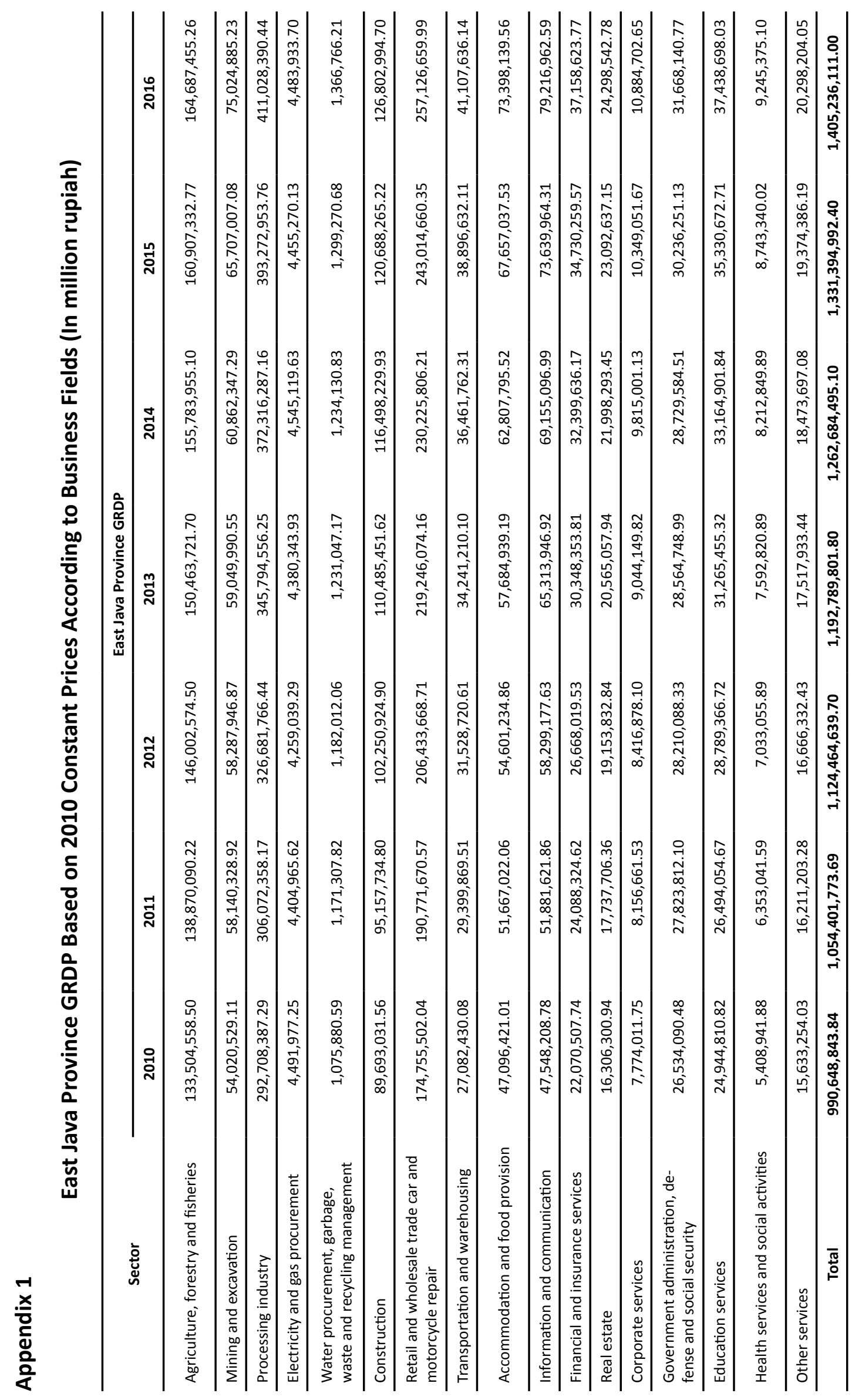




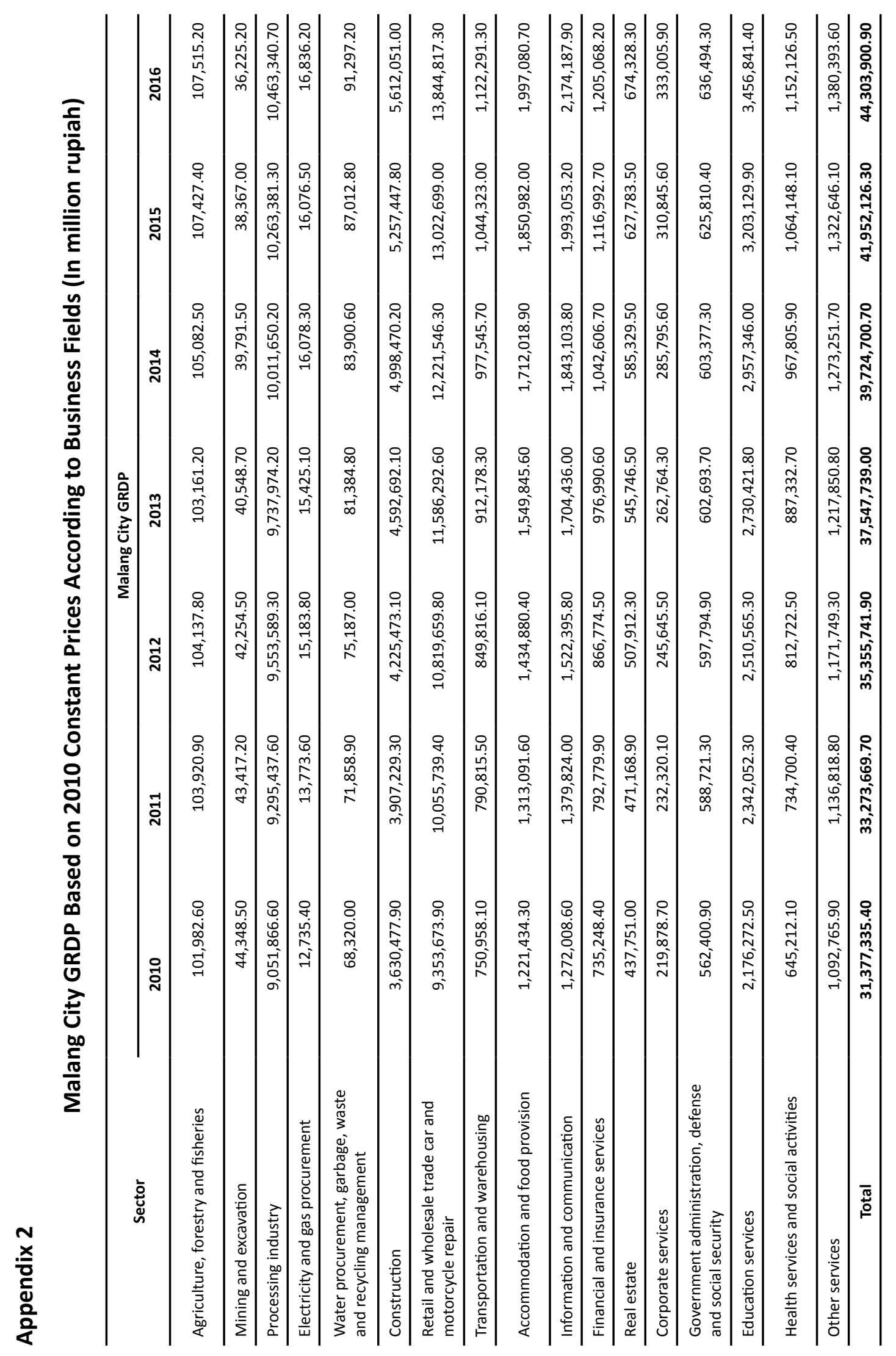




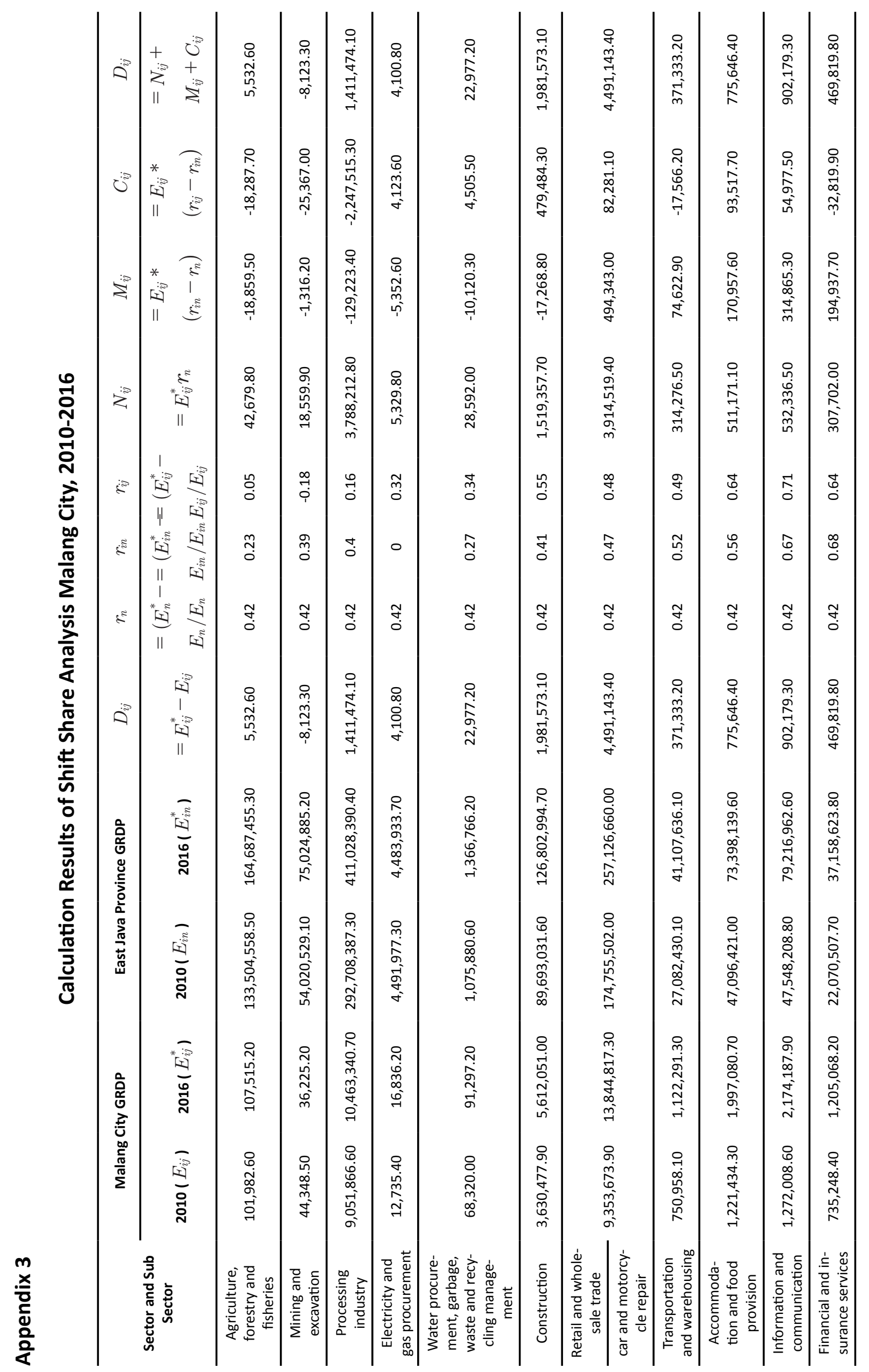




\begin{tabular}{|c|c|c|c|c|c|c|c|c|}
\hline 8 & $\begin{array}{ll}+ & 0 \\
+ & 0 \\
z & + \\
\| & \vdots\end{array}$ & 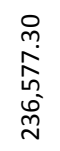 & 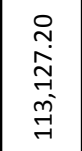 & 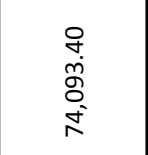 & 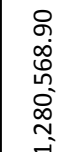 & 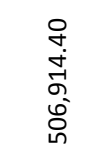 & 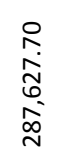 & 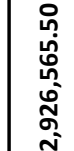 \\
\hline 8 & 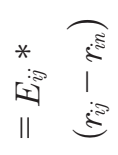 & 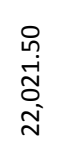 & 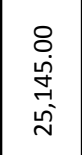 & 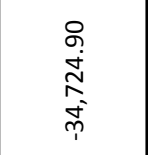 & 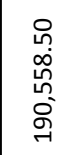 & 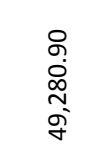 & 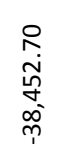 & 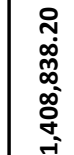 \\
\hline$\Sigma$ & 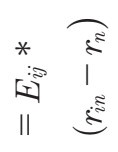 & $\begin{array}{l}\stackrel{p}{0} \\
0 \\
0 \\
m \\
m \\
m\end{array}$ & 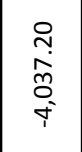 & $\begin{array}{l}8 \\
8 \\
0 \\
0 \\
0 \\
0 \\
7 \\
1\end{array}$ & 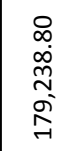 & 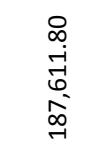 & 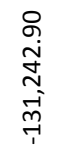 & 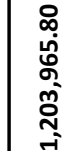 \\
\hline$z$ & 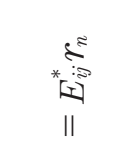 & 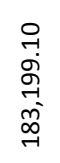 & 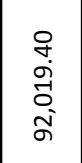 & 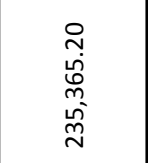 & 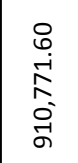 & 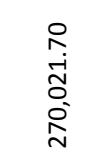 & $\begin{array}{l}\stackrel{p}{m} \\
\stackrel{n}{m} \\
\stackrel{n}{q}\end{array}$ & 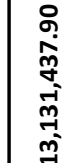 \\
\hline$\therefore$ & 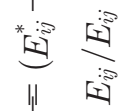 & $\begin{array}{l}\text { Hु } \\
\text { مू }\end{array}$ & in & $\stackrel{m}{0}$ & 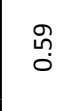 & $\begin{array}{l}\stackrel{r}{0} \\
0\end{array}$ & 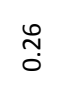 & \\
\hline है & $\underbrace{*+5}_{\|}$ & g̊ & $\stackrel{\circ}{\circ}$ & ?ํํㅇ & ֻ & î. & $\stackrel{m}{\circ}$ & \\
\hline \& & $\underbrace{*}_{\|}$돌 & ริ & fี & f̊ & $\stackrel{\text { Fิ }}{0}$ & f & f̊ & \\
\hline 5 & 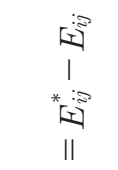 & $\begin{array}{l}\stackrel{0}{m} \\
\stackrel{n}{n} \\
\text { do } \\
\stackrel{n}{n}\end{array}$ & 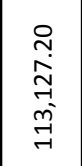 & 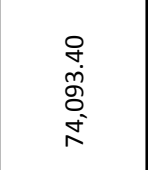 & 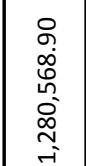 & 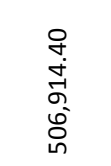 & 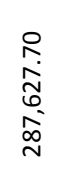 & 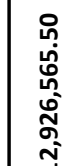 \\
\hline & 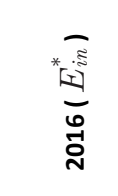 & 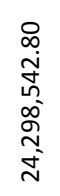 & 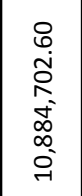 & 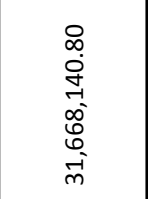 & 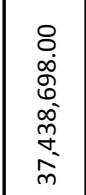 & 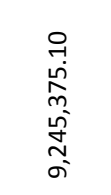 & 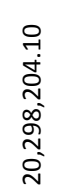 & 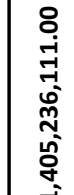 \\
\hline & 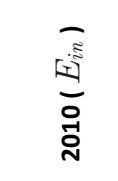 & 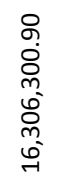 & 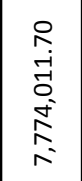 & 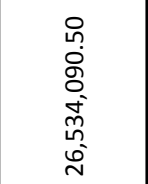 & 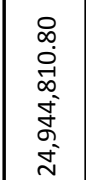 & 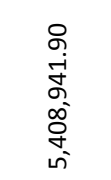 & 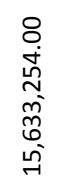 & $\begin{array}{l}0 \\
\infty \\
\tilde{m} \\
\infty \\
\infty \\
\infty \\
0 \\
0 \\
0 \\
0\end{array}$ \\
\hline & 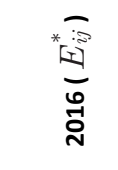 & 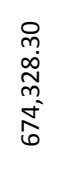 & $\begin{array}{l}\text { o } \\
\text { ¿े } \\
\text { ले } \\
\text { m. }\end{array}$ & 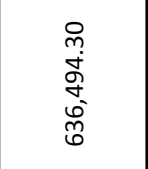 & 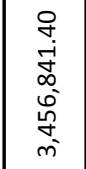 & 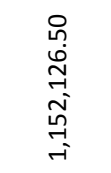 & 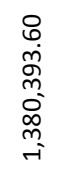 & 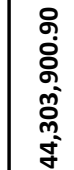 \\
\hline & 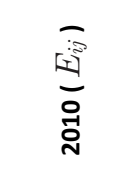 & 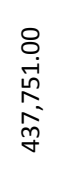 & 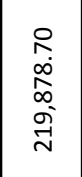 & 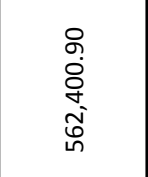 & 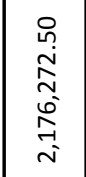 & 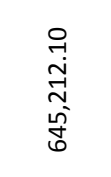 & 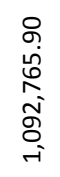 & 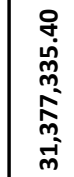 \\
\hline & 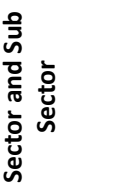 & 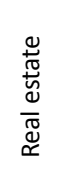 & 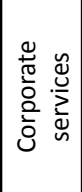 & 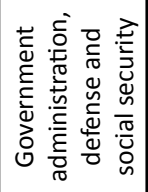 & 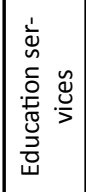 & 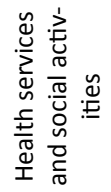 & 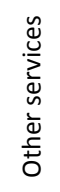 & 䙲 \\
\hline
\end{tabular}




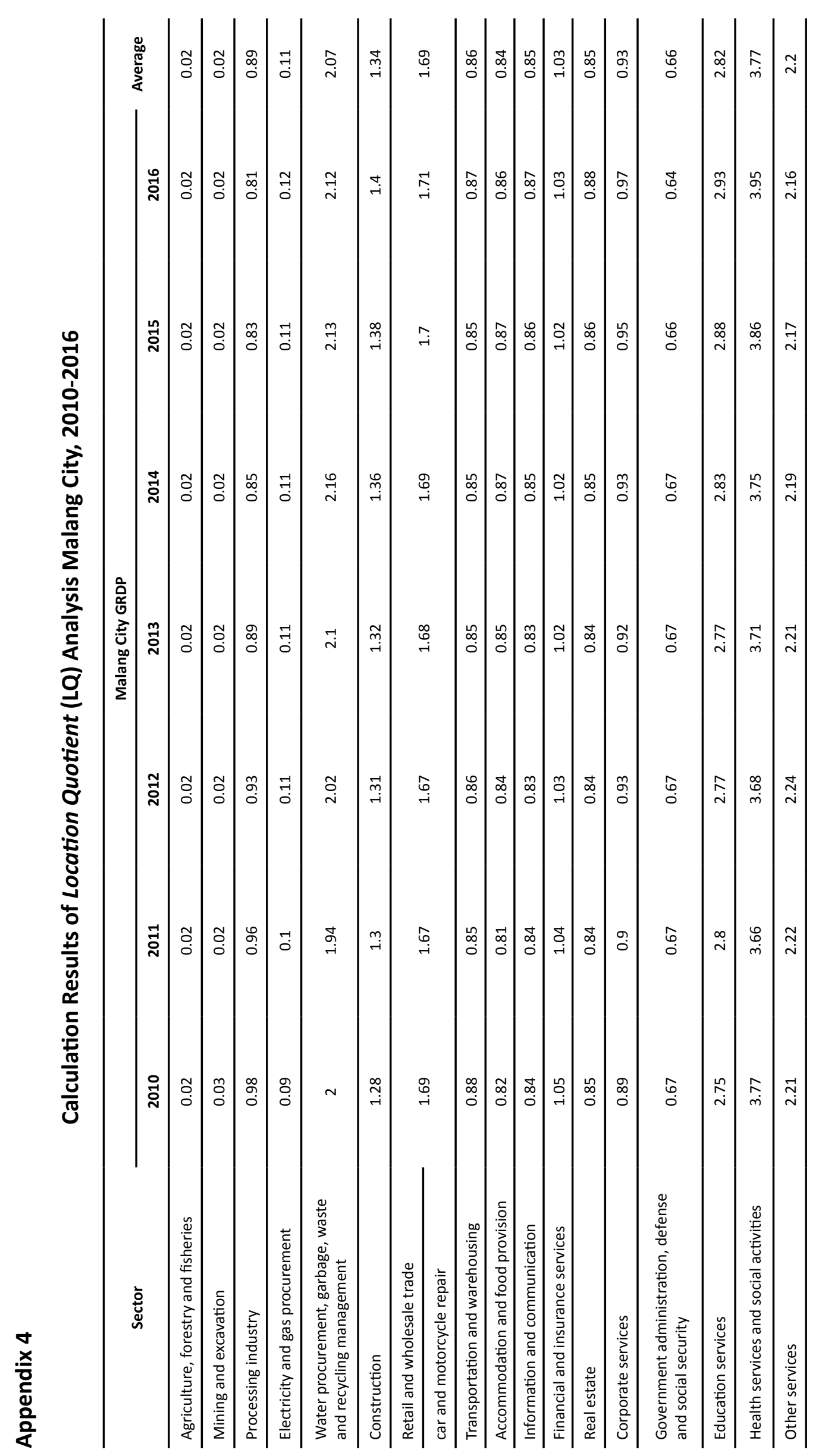




\section{Appendix 5}

Calculation Results of Growth Ratio Model (GRM) Analysis Malang City, 2010-2016

\begin{tabular}{|c|c|c|c|c|}
\hline \multirow{3}{*}{ Sector } & \multicolumn{4}{|c|}{ Growth Ratio Model } \\
\hline & \multicolumn{2}{|c|}{ RPR } & \multicolumn{2}{|c|}{ RPS } \\
\hline & $\mathbf{R}$ & $\mathbf{N}$ & $\mathbf{R}$ & $\mathbf{N}$ \\
\hline Agriculture, forestry and fisheries & 0.56 & - & 0.13 & - \\
\hline Mining and excavation & 0.93 & - & -0.44 & - \\
\hline Processing industry & 0.97 & - & 0.38 & - \\
\hline Electricity and gas procurement & 0 & - & 0.78 & - \\
\hline Water procurement, garbage, waste and recycling management & 0.65 & - & 0.82 & - \\
\hline Construction & 0.99 & - & 1.32 & + \\
\hline \multicolumn{5}{|l|}{ Retail and wholesale trade } \\
\hline \multicolumn{5}{|l|}{ car and motorcycle repair } \\
\hline Transportation and warehousing & 1.24 & + & 1.2 & + \\
\hline Accommodation and food provision & 1.33 & + & 1.54 & + \\
\hline Information and communication & 1.59 & + & 1.72 & + \\
\hline Financial and insurance services & 1.63 & + & 1.55 & + \\
\hline Real estate & 1.17 & + & 1.31 & + \\
\hline Corporate services & 0.96 & - & 1.25 & + \\
\hline Government administration, defense and social security & 0.46 & - & 0.32 & - \\
\hline Education services & 1.2 & + & 1.43 & + \\
\hline Health services and social activities & 1.69 & + & 1.91 & + \\
\hline Other services & 0.71 & - & 0.64 & - \\
\hline
\end{tabular}




\section{Appendix 6}

\section{Weighting Results Based on Shift-Share, Location Quotient (LQ) andGrowth Ratio Model (GRM) Analysis Malang City, 2010 - 2016}

\begin{tabular}{|c|c|c|c|c|c|c|c|c|}
\hline Sector & $\begin{array}{l}\text { Shift Share } \\
\left(D_{i j}\right)\end{array}$ & Value & LQ & Value & MRP (RPs) & Value & Total Value & Rank \\
\hline Agriculture, forestry and fisheries & $5,532.60$ & 3 & 0.022 & 2 & 0.132 & 2 & 7 & 13 \\
\hline Mining and excavation & $-8,123.30$ & 1 & 0.021 & 1 & -0.445 & 1 & 3 & 14 \\
\hline Processing industry & $1,411,474.10$ & 15 & 0.893 & 9 & 0.379 & 4 & 28 & 8 \\
\hline Electricity and gas procurement & $4,100.80$ & 2 & 0.109 & 3 & 0.782 & 6 & 11 & 12 \\
\hline $\begin{array}{l}\text { Water procurement, garbage, waste } \\
\text { and recycling management }\end{array}$ & $22,977.20$ & 4 & 2.068 & 14 & 0.816 & 7 & 25 & 10 \\
\hline Construction & $1,981,573.10$ & 16 & 1.338 & 12 & 1.325 & 12 & 40 & 3 \\
\hline Retail and wholesale trade & \multirow{2}{*}{$4,491,143.40$} & \multirow{2}{*}{17} & \multirow{2}{*}{1.686} & \multirow{2}{*}{13} & \multirow{2}{*}{1.165} & \multirow{2}{*}{8} & \multirow{2}{*}{38} & \multirow{2}{*}{4} \\
\hline car and motorcycle repair & & & & & & & & \\
\hline Transportation and warehousing & $371,333.20$ & 9 & 0.857 & 8 & 1.2 & 9 & 26 & 9 \\
\hline Accommodation and food provision & $775,646.40$ & 12 & 0.844 & 5 & 1.541 & 14 & 31 & 7 \\
\hline Information and communication & $902,179.30$ & 13 & 0.846 & 6 & 1.722 & 16 & 35 & 6 \\
\hline Financial and insurance services & $469,819.80$ & 10 & 1.032 & 11 & 1.551 & 15 & 36 & 5 \\
\hline Real estate & $236,577.30$ & 7 & 0.852 & 7 & 1.312 & 11 & 25 & 10 \\
\hline Corporate services & $113,127.20$ & 6 & 0.928 & 10 & 1.249 & 10 & 26 & 9 \\
\hline $\begin{array}{l}\text { Government administration, de- } \\
\text { fense and social security }\end{array}$ & $74,093.40$ & 5 & 0.664 & 4 & 0.32 & 3 & 12 & 11 \\
\hline Education services & $1,280,568.90$ & 14 & 2.821 & 16 & 1.428 & 13 & 43 & 2 \\
\hline Health services and social activities & $506,914.40$ & 11 & 3.768 & 17 & 1.907 & 17 & 45 & 1 \\
\hline Other services & $287,627.70$ & 8 & 2.198 & 15 & 0.639 & 5 & 28 & 8 \\
\hline
\end{tabular}

